Western University

Scholarship@Western

Aboriginal Policy Research Consortium International (APRCi)

3-18-2009

\title{
Canada and the Legacy of the Indian Residential Schools: transitional justice for indigenous people in a non-transitional society
}

CourtneyJung

Follow this and additional works at: https://ir.lib.uwo.ca/aprci

Part of the Other Sociology Commons

Citation of this paper:

Jung, Courtney, "Canada and the Legacy of the Indian Residential Schools: transitional justice for indigenous people in a nontransitional society" (2009). Aboriginal Policy Research Consortium International (APRCi). 295.

https://ir.lib.uwo.ca/aprci/295 
Canada and the Legacy of the Indian Residential Schools: transitional justice for indigenous people in a non-transitional society

Courtney Jung ${ }^{1}$

March 18, 2009

The framework of transitional justice, originally devised to facilitate reconciliation in countries undergoing transitions from authoritarianism to democracy, is used with increasing frequency to respond to certain types of human rights violations against indigenous peoples. ${ }^{2}$ In some cases, transitional justice measures are employed in societies not undergoing regime transition. Transitional justice measures offer opportunities for re-inscribing the responsibility of states toward their indigenous populations, empowering indigenous communities, responding to indigenous demands to be heard, and rewriting history. Nevertheless, treating indigenous demands for justice as a matter of "human rights" is an ethically loaded project that may reinforce liberal (and neo-liberal) paradigms that indigenous peoples often reject. Whether transitional justice measures will serve primarily to legitimate the status quo between postcolonial states, settler societies, and Aboriginal peoples, or whether they will have transformational capacity, will depend in part on the political context in which they take place. The impact of such transitional justice measures as apologies, truth commissions, and reparations will be limited, or extended, by the wider policy environment in which they occur.

This paper outlines some of the potential complexities involved in processing indigenous demands for justice through a transitional justice framework. It identifies three broad areas in which the interests and goals of governments and indigenous peoples may clash, and where transitional justice itself may be the object of political wrangling. First, governments and indigenous peoples may differ over the scope of injustices that transitional justice measures can address. Second, governments may try to use transitional justice to draw a line through history and legitimate present policy, whereas indigenous peoples may try to use the past to critique present policy and conditions. Third, governments may try to use transitional justice to reassert their sovereign and legal authority, whereas indigenous peoples may try to resist this strategy, and even make competing claims to sovereignty and legal authority.

Recent developments in the relationship between the Canadian government and First Nations highlight the challenges and opportunities of addressing indigenous demands for justice through the lens of transitional justice. In May 2006, the government, the Churches, and the Assembly of First Nations and other Aboriginal organizations reached agreement on a settlement to address the legacy of the Indian Residential School system ${ }^{3}$. The agreement included reparations, a truth commission, and commemoration. In June 2008, Conservative Prime Minister Stephen Harper

\footnotetext{
${ }^{1}$ The author would like to thank Paige Arthur, Gina Cosentino, Eduardo Gonzalez, and Patrick Macklem for helpful comments and insight on this paper. The analysis and conclusions are the sole responsibility of the author.

${ }^{2}$ On the intellectual history of transitional justice, see Paige Arthur, "How 'Transitions' Re-shaped Human Rights: A Conceptual History of Transitional Justice" Full reference?

${ }^{3}$ The Assembly of First Nations is an organization of First Nations chiefs that acts as the national political representative of First Nations governments and their citizens in Canada. The AFN is funded by the government, and has an office in Ottawa. The National Chief is elected by the Assembly of Chiefs, and plays a prominent role in responding to and shaping government initiatives that impact aboriginal people.
} 
offered an official state apology to former students of Indian Residential Schools. Both the Harper government and First Nations leaders seem keen to employ transitional justice measures to deal with the legacy of the Residential School system. Nevertheless, they have different reasons for endorsing a transitional justice framework, and distinct perspectives on the work and goals of the apology, the Truth and Reconciliation Commission, and compensation.

\section{The scope of injustice}

Almost every dimension of indigenous life has been shaped, and limited, by the colonial encounter and by a post-colonial history of dispossession, racism, exclusion, betrayal, and forced assimilation. The indigenous experience is one of loss of land and sovereignty, the loss or devaluation of language and culture, loss of access to resources, and limited access to the socioeconomic and political rights of citizenship. The scope of the wrongs that have been committed against indigenous people is extensive. As a result, indigenous demands for justice are wide-ranging.

But transitional justice measures are limited. In Canada, the apology, the TRC, and compensation are designed to address only the legacy of the residential schools system. Yet the residential school system is a narrow slice of the outstanding issues that bedevil the relationship between aboriginals, the Canadian government, and non-aboriginal Canadians. In the last fifteen years alone there have been two major government initiatives that proposed serious and wide ranging transformation of Canada-First Nations relations - the Royal Commission on Aboriginal Peoples and the Kelowna Accord. But both floundered, and the Conservative government entered office in January 2006 with little more than a controversial proposal to "extend human rights to First Nations" in a way that threatened to undermine aboriginal collective rights. The government has attempted to use "human rights" as a strategy for limiting state obligation, and as a wedge to undermine indigenous collective rights to self determination. Although the Conservative government did not initiate the transitional justice project that is now the centerpiece of its aboriginal policy, transitional justice extends the party's human rights agenda, and is offered as an alternative to constitutional transformation and social justice.

In 1991, the Government of Canada established the Royal Commission on Aboriginal Peoples ("RCAP") to investigate the social, economic and political conditions of the Aboriginal peoples of Canada, and to develop recommendations focused on the improvement of these conditions, and the overall relationship between First Nations and the Crown. The Commissioners directed their consultations to one over-riding, and extremely broad, question: What are the foundations of a fair and honorable relationship between the Aboriginal and non-Aboriginal people of Canada? The Commission held 178 days of public hearings, visited 96 communities, consulted dozens of experts, commissioned scores of research studies, and reviewed numerous past inquiries and reports. Their central conclusion was that the main policy direction, pursued for more than 150 years, first by colonial then by Canadian governments, has been wrong. ${ }^{4}$

The Royal Commission released its final report and recommendations in November, 1996. The report was five volumes long, including 4,000 pages and 440 recommendations. The first

\footnotetext{
${ }^{4}$ Highlights from the report of the Royal Commission on Aboriginal Peoples, online at www.aincinac.gc.ca/ap/pubs/rpt/rpt-eng.asp
} 
volume traces the history of the relationship between aboriginals and the state, details various failed policies, including the Indian Residential Schools policy, and proposes a new path forward. Volume two lays out the laws that presently govern First Nations, including treaty rights, existing financial arrangements for aboriginal governments, land provisions, and comanagement agreements. Volume three recommends new directions in social policy in the areas of housing, education, language preservation, health, family and child welfare, arts and heritage, and museums. Volume four articulates the views of Aboriginals themselves. It includes sections on the perspectives of Elders, women, youth, Metis, and urban aboriginals. Volume five is titled "Renewal: A Twenty Year Commitment." The two central planks of the commitment are redressing economic and welfare disparity, and constitutional reform.

Fourteen months later, in January 1998, the government unveiled its response to the RCAP report: "Gathering Strength-Canada's Aboriginal Action Plan." The Action Plan had four components: renewing the partnership, strengthening aboriginal governance, developing a new fiscal relationship, and supporting strong communities, people, and economics. Nevertheless, in April 1999 the Human Rights Committee of the United Nations High Commissioner for Human Rights released its concluding observations on Canada's observance of UN Human Rights Covenants. "...the Committee is particularly concerned that the State party (Canada) has not yet implemented the recommendations of the Royal Commission on Aboriginal Peoples." In fact, ten years later it is generally acknowledged that, although the government launched a few minor initiatives based in part on RCAP recommendations, the transformational spirit and intent of the Commission has been squandered. ${ }^{5}$

The next major aboriginal initiative was the Kelowna Accord. The Kelowna Accord is a series of agreements between the Government of Canada, First Ministers of the Provinces, Territorial Leaders, and the leaders of five national aboriginal organizations in Canada, including the Assembly of First Nations. The agreements resulted from 18 months of roundtable consultations culminating in a First Ministers' Meeting in Kelowna, British Columbia in November 2005. The Accord committed the government to spend five billion dollars over ten years to improve the education, employment, and living conditions of Aboriginal peoples, and it was welcomed by aboriginal leaders for involving a process of cooperation and consultation. Fontaine identified the Kelowna agreement as a "comprehensive, practical approach" to "the single most important social justice issue facing the country" and Paul Martin singled out the agreement as the "crowning achievement" of his term as prime minister. ${ }^{6}$

Nevertheless, when the Liberal government of Paul Martin fell in January 2006, the Conservative incumbents insisted that the Kelowna Accord "did not exist" because funds had not been budgeted for its implementation. ${ }^{7}$ Under the leadership of Prime Minister Stephen Harper, the Conservative government has ignored the Kelowna Accord, and in June 2006 it tabled a new budget that dedicated few new resources to First Nations. Two days later, Paul Martin

\footnotetext{
5 “Implement Kelowna Deal on Native Poverty: Fontaine” CBC News, November 21, 2006 www.cbc.ca/canada/story/2006/11/21/fontaine-kelowna.html

6 "Implement Kelowna Deal on Native Poverty: Fontaine" CBC News, November 21, 2006 www.cbc.ca/canada/story/2006/11/21/fontaine-kelowna.html

7 "There is no Kelowna Accord": Jim Prentice to the House of Commons" e-note by Four Arrows 9 June 2007
} 
introduced a private members bill, calling on the government to follow through on the promises laid out in the Kelowna Accord. The bill passed by a vote of 176-126, but private members bills cannot compel government to spend money, and the Conservatives ignored the vote. ${ }^{8}$

Instead, the Conservative government came into office with its own aboriginal initiative, Bill C44, an Act to amend the Canadian Human Rights Act by removing the exemption (Section 67) that shields the federal government and First Nations governments "from complaints of discrimination relating to actions arising from or pursuant to the Indian Act." While the proposal is often described as extending human rights to First Nations people living on reserves, in fact aboriginals already enjoyed the general protection of the Canadian Human Rights Act, except in special situations where their rights and status are governed by the Indian Act. What is more, the Section 67 exemption had no effect on Charter-based equality rights. ${ }^{9}$

The amendment received first reading in the House of Commons in December 2006, and was referred to the House of Commons Standing Committee on Aboriginal Affairs and Northern Development. That committee deliberated on the Bill in sixteen meetings between March and June 2007, and heard a number of expert witnesses who raised serious concerns about the process and substance of the legislation. In June 2007 the Committee adopted an opposition motion recommending that debate on the repeal be suspended for up to ten months to allow the government to initiate a broad consultative process to include First Nations representatives. In July 2007 a majority of members were called back, by the Conservative Party, to an unusual midsummer meeting for a clause-by-clause consideration of the Bill. Again, the opposition voted to suspend such consideration pending consultations, and the Bill died when parliament was prorogued in September 2007. Two months later the government introduced Bill C-21, which was identical to Bill C-44. That Bill was finally passed in June 2008 with five significant opposition amendments. ${ }^{10}$

First Nations representatives and expert non-governmental witnesses had five major concerns regarding Bill C-44. First, they argued that a human rights bill must include a non-derogation clause to protect Aboriginal and Treaty rights. Second, they insisted that the Bill include an interpretive provision to guide the Canadian Human Rights Commission, tribunals, and courts in balancing individual human rights and the collective constitutional rights of First Nations. Third, they requested a 36 month transition period to develop the critical capacity to implement CHRA provisions. Fourth, they requested funding to help First Nations governments respond to human rights complaints. Fifth, they recommended that complaints against First Nations governments be considered by independent First Nations institutions.

\footnotetext{
8 “Tories to Ignore Parliament's Kelowna Accord vote" /www.ctv.ca/servlet/ArticleNews/story/CTVNews/20070321/kelowna_vote_070321?s_name=\&no_ads=

9 "Bill C-44: An Act to amend the Canadian Human Rights Act" Prepared by Mary Hurley, Law and Government Division 16 January 2007, Legislative Summaries (Library of Parliament - Parliamentary Information and Research Service)

10 "Bill C-21: An Act to amend the Canadian Human Rights Act" Prepared by Mary Hurley, Law and Government Division Revised 30 June 2008Legislative Summaries (Library of Parliament - Parliamentary Information and Research Service) www.parl.gc.ca/common/bills_ls.asp?lang=E\&ls=c21\&source=library_prb\&Parl=39\&Ses=2
} 
Specifically, while First Nations representatives insisted on their own commitment to ensuring the full range of human rights for their people, they were concerned that an equality framework would expose First Nations governments to allegations of preferential treatment toward band members. Several expert witnesses insisted that the repeal of Section 67 "could cause the Indian Act to unravel, dispossessing hundreds of First Nation communities across Canada from their reserve lands." 11 One way it might do so is by allowing non-aboriginal people to challenge health and education benefits provided to aboriginal people alone. ${ }^{12}$ Non-aboriginals may also have been able to challenge the special land, fishing, logging, and other rights that aboriginals have secured, in part through the Indian Act.

Under the circumstances, aboriginal representatives had reason to be wary of the Conservative government's intentions in introducing Bill C-44. Harper's closest advisor, Tom Flanagan, has written a book titled First Nation? Second Thoughts, in which he argues that aboriginals are immigrants who should be assimilated, and he has appeared as an expert witness against aboriginal land claims. Harper's first Minister of Indian Affairs was Jim Prentice, a property rights lawyer who has argued for extending property rights to reserves, and is also known for his opposition to native land claims. ${ }^{13}$ Property rights are another way of extending individual rights to band members in a way that threatens collective rights and, indigenous leaders fear, may ultimately lead to land alienation.

In the end, Bill C-21 was amended by opposition members on the committee to include some of the exemptions and caveats recommended by First Nations and expert witnesses. In particular the final Bill stated that "The repeal of section 67 of the Canadian Human Rights Act shall not be construed so as to abrogate or derogate from any aboriginal, treaty or other rights or freedoms that pertain to the First Nations peoples of Canada, including: 1) any rights or freedoms that have been recognized by the Royal Proclamation of October 7,1763 ; 2) any rights or freedoms that now exist by way of land claims agreements or may be so acquired; and 3) any rights or freedoms recognized under the customary laws or traditions of the First Nations peoples of Canada." In addition, "In relation to a complaint made under the Canadian Human Rights Act against a First Nation government, including a band council, tribal council or governing authority operating or administering programs and services under the Indian Act, this Act shall be interpreted and applied in a manner that gives due regard to First Nations legal traditions and customary laws, particularly the balancing of individual rights and interests against collective rights and interests." 14

\footnotetext{
11 “AFN, Opposition Stiffen Resistance to Bill C-44, Legal Experts Cite Grave Problems with Bill” e-notes from four arrows@canada.com 9 June 2007 Edition www.gatheringplacefirstnationscanews.ca/Governance/Rarihokwats/prentice\%20on\%20kelowna.pdf

12 Testimony provided by William Black, Professor of Human Rights Law, Faculty of Law, University of British Columbia, cited in ibid., p. 2

13 “Aboriginal agenda conflicts with background of Harper advisors, lead advisor Tom Flanagan has made a career of opposing land claims" Harper Index, May 16, 2007 www.harperindex.ca/ViewArticle.cfm?Ref=0022

${ }^{14}$ Mary C. Hurley, "Bill C-21: An Act to amend the Canadian Human Rights Act" Legislative Summaries, Library of Parliament, Parliamentary Information and Research Service 14 November 2007, Revised 30 June 2008 www.parl.gc.ca/common/bills_ls.asp?lang=E\&ls=c21\&source=library_prb\&Parl=39\&Ses=2\#description
} 
Nevertheless, conservative commentators hailed the bill as "a good first step toward solving the much bigger problem of treating Native people as though they are different from the rest of the country, clearing up any misunderstanding that some may have about Natives being a "sovereign nation"."15 Notwithstanding the opposition amendments, the repeal of Section 67 of the Constitution is significant. It remains to be seen how much weight courts will assign to the nonderogation and interpretive clauses the Bill includes. How much protection those amendments will actually offer to band governments has yet to be tested in court. As the Bill moved into the Senate, Indian Affairs Minister Chuck Strahl clarified the relationship between C 21 and the UN Declaration on the Rights of Indigenous Peoples, explaining "Our government believes that delivering real human rights to First Nations peoples, as this Bill does, is much more important and tangible than any aspirational document." 16 The Harper government has been insistent that their commitment to human rights justifies their refusal to ratify the UN Declaration. ${ }^{17}$

Against the backdrop of these other policy initiatives, successive Canadian governments have struggled to address the legacy of the Indian Residential School policy. For roughly one hundred years, between the late nineteenth and late twentieth centuries, the government of Canada collaborated with various churches to operate a residential school system that forcibly removed aboriginal children from their parents and communities and placed them in boarding schools. ${ }^{18}$ Approximately 150,000 children were sent to residential schools. Starting from only two schools in operation when Canada was formed in $1867,{ }^{19}$ a total of 130 residential schools existed over time. $^{20}$

The explicit purpose of the residential schools was to destroy aboriginal language and culture, "to take the Indian out of the child." Students were not allowed to speak their own languages at school, and their cultures and heritages were debased. Children also suffered physical harm.

Some schools had mortality rates of 35 to 60 percent, due to malnutrition, abuse, and exposure to tuberculosis, and many children were victims of physical and sexual abuse. Through the Residential School System, the government of Canada violated human rights to bodily integrity, equality, privacy, education, culture, family, and life.

\footnotetext{
15 "Bill helps dispel sovereign nation notion," Caledonia Wake-up Call.com http://caledoniawakeupcall.wordpress.com/2008/06/27/bill-c-21-helps-dispel-\%E2\%80\%9Csovereignnation\%E2\%80\%9D-notion/

${ }^{16}$ STATEMENT BY THE HONOURABLE CHUCK STRAHL IN RELATION TO BILL C-21, AN ACT TO AMEND THE CANADIAN HUMAN RIGHTS ACT May 28, 2008 on Indian and Northern Affairs Canada (INAC) Ministry website www.ainc-inac.gc.ca/ai/mr/nr/m-a2008/2-3044-eng.asp?p1=209557\&p2=6139

${ }^{17}$ "Canada taking 'bold steps' on aboriginal issues, Strahl tells UN" CBCnews.ca May 1, 2008 www.cbc.ca/canada/story/2008/05/01/un-strahl.html

${ }^{18}$ See Agnes Grant, No End of Grief: Indian Residential Schools in Canada (Winnipeg, Pemmican Publications, Inc., 1996), 64; Report of the Royal Commission on Aboriginal Peoples, Vol.1 (Ottawa: Minister of Supply and Services Canada, 1996), Ch.10, "Residential Schools," 343 [hereinafter, "RCAP Report"]; Indian Residential Schools Resolution, "Backgrounder: Federal representative to lead discussions toward a lasting resolution of the legacy of Indian residential schools," June 8, 2005, available at www.irsr.gc.ca/english/federal_repre.html [hereinafter "IRSR Backgrounder"]; Indian and Northern Affairs Canada, "Backgrounder: The Residential Schools System," last updated April 23, 2004, available at www.ainc-inac.gc.ca/gs/schl_e.html [hereinafter, "INAC Backgrounder"].

${ }^{19}$ RCAP Report, 353.

${ }^{20}$ INAC Backgrounder.
} 
Injustices associated with residential schools assumed mainstream political and legal significance in the late 1980s. Commencing in 1989-1990, prosecutions against former residential school staff began in British Columbia and the Yukon, spurring additional police investigations and, in turn, further prosecutions. ${ }^{21}$ By 1992, most churches had apologized for their conduct, but also asserted "shared responsibility" with the federal government for the consequences of the residential school system. ${ }^{22}$ The RCAP report detailed widespread neglect, governmental underfunding, health-related problems, as well as sexual, physical, and emotional abuse endured by students over many years, and called for a public inquiry into the policy. ${ }^{23}$

In response to the RCAP report, Jane Stewart, then Minister for Indian Affairs and Northern Development, issued a Statement of Reconciliation in 1998, acknowledging the federal government's role in the development and administration of the residential schools, and expressing regret to those students who experienced sexual and physical abuse. ${ }^{24}$ The Statement of Reconciliation was part of a four-part strategy that included a commitment of $\$ 350$ million for community-based healing for those suffering the effects of physical and sexual abuse in residential schools, a revision of litigation strategy, and the implementation of alternative dispute resolution (ADR) mechanisms to avoid lengthy and expensive litigation. ${ }^{25}$ Nevertheless, by October 2002, more than 11,000 legal cases had been filed against the federal government and the churches. ${ }^{26}$

In March 2004 the Assembly of First Nations issued a scathing critique of the government's ADR process, arguing that it perpetuated racial stereotypes, treated survivors unequally, measured abuse in accordance with the "standards of the day," and failed to compensate for loss

\footnotetext{
${ }^{21}$ RCAP Report, 378.

${ }^{22}$ RCAP Report, 379-380.

${ }^{23}$ RCAP Report, 383. According to the report, "The public inquiry's main focus should be to investigate and document the origins, purposes, and effects of residential school policies and practices as they relate to all Aboriginal peoples, with particular attention to the manner and extent of their impact on individuals and families across several generations, on communities, and on Aboriginal society as a whole. The inquiry should conduct public hearings across the country, with sufficient funding to enable those affected to testify. The inquiry should be empowered to commission research and analysis to assist in gaining an understanding of the nature and effects of residential school policies. It should be authorized to recommend whatever remedial action it believes necessary for governments and churches to ameliorate the conditions created by the residential school experience. Where appropriate, such remedies should include apologies from those responsible, compensation on a collective basis to enable Aboriginal communities to design and administer programs that assist the healing process and rebuild community life, and funding for the treatment of affected people and their families". Ibid.

${ }^{24}$ Indian and Northern Affairs Canada, "Statement of Reconciliation: Learning from the Past," last updated April 24, 2004; available at www.ainc-inac.gc.ca/gs/rec_e.html. See also Indian and Northern Affairs Canada, Gathering Strength: Canada's Aboriginal Action Plan (Ottawa: Minister of Indian Affairs and Northern Development, 1997); available at www.ainc-inac.gc.ca/gs/chg_e.html (hereinafter "Gathering Strength").

${ }^{25}$ Gathering Strength, ibid.. See also Indian and Northern Affairs Canada and First Nations and Inuit Health Branch , The Path to Healing , February 1998, < http://www.ainc-inac.gc.ca/gs/pth_e.html > last accessed September 1, 2005.

${ }^{26}$ Kaufman, Thomas and Associates, "Review of Indian Residential Schools Dispute Resolution Projects," Final Report, Executive Summary, October 11, 2002, www.afn.ca/residentialschools/PDF/ADR-reportFinal_english.pdf ; Pamela O'Connor, "Squaring the Circle: How Canada is Dealing with the Legacy of its Indian Residential Schools Experiment," International Journal of Legal Information 28 (2000), 251.
} 
of language and culture. ${ }^{27}$ The overriding complaint was that the government's framework for resolving residential schools claims was inadequate and too slow. The government too was dissatisfied with the ADR framework, which had failed to stem the tide of lawsuits against the federal government and the churches. In May 2005, the government signed a Political Agreement, promising negotiations toward "a settlement package that will address a redress payment for all former students of Indian residential schools, a truth and reconciliation process, community based healing, commemoration, an appropriate ADR process that will address serious abuse, as well as legal fees." 28

The ink was barely dry on the Political Agreement when, on August 5, 2005, the AFN launched a class action lawsuit against the federal government on behalf of four proposed sub-classes: survivors, deceased, Aboriginal and family. ${ }^{29}$ Chief Phil Fontaine, leader of the AFN and a residential school survivor, was named as the proposed representative of the Survivor and Aboriginal sub-classes. In addition to various declarations, the AFN sought twelve billion dollars in general damages, twelve billion dollars in special damages for negligence, breach of fiduciary, statutory, treaty and other common law duties, and twelve billion dollars in punitive damages. ${ }^{30}$ The AFN further sought the establishment of a fund "whose objects are to create, support, develop, enhance and expand programs designed to mitigate the Cultural, Linguistic and Social Damage caused by the Crown's Residential Schools Policy.",31

According to Chief Fontaine: "Our action is not an attempt to impede the process, but rather a means to ensure that we are able to fully participate in the process, more effectively settle this to the benefit of all residential schools survivors and all First Nations citizens affected by the residential schools, and to ensure that all options remain open for them. The [Political Agreement] has provided a political vehicle to move forward, but a legal vehicle is required to finalize the process with the AFN in a central and representative role, which this action now provides." 32

On May 10, 2006, the Government announced the approval by all parties of the Indian Residential Schools Settlement Agreement (IRSSA), an out-of-court settlement that represents the consensus reached in the discussions between the government of Canada, legal counsel for former students, the churches, the Assembly of First Nations and other Aboriginal organizations. It is the largest, most complex, class action settlement in Canadian history. The IRSSA was

\footnotetext{
${ }^{27}$ Assembly of First Nations. 2004. Assembly of First Nations report on Canada's dispute resolution plan to compensate for abuses in Indian residential schools. Ottawa, Ont: Assembly of First Nations. http://site.ebrary.com/lib/albertacel/Doc?id=10185110.

28 "Political Agreement," Online at the Federal Representative website "Federal Representative-Indian Residential Schools" www.iacobucci.gc.ca/doc-eng.asp?action=20050530pa

${ }^{29}$ Larry Philip Fontaine et al. v. The Attorney General of Canada, Ontario Court File No. 05-CV-294716 CP (issued August 5, 2005).

${ }^{30}$ Statement of Claim, para. 2 (j)-(1).

${ }^{31}$ Statement of Claim, para. 2(i).

32 Assembly of First Nations, "AFN National Chief Files Class Action Claim Against the Government of Canada for Residential Schools Policy,” press release, August 3, 2005; available at www.afn.ca/article.asp?id=1632. While Fontaine claimed he had few substantive reservations about the Political Agreement, he launched the class action suit in order to re-shape the process. He wanted the final settlement to be negotiated among equals (parties to a legal case), and he wanted it to be legally binding, so that the government could not renege on an agreement.
} 
approved by the courts and came into effect on September 19, 2007. The Settlement Agreement includes five important components of transitional justice: a "common experience" payment; an independent assessment process; a truth and reconciliation commission; commemoration; and healing. ${ }^{33}$

Against this backdrop, the scope of transitional justice is likely to be highly politicized. When governments and indigenous groups agree to employ a transitional justice framework to address a discrete segment of the historical injustices that have structured relations between them, they are likely to try to use that framework for different purposes. The government may try to use such measures as apologies and reparations to shut down other indigenous demands, offering transitional justice in exchange for quiescence on other issues. In particular, a transitional justice framework may channel indigenous politics into a human rights framework as a way to undermine indigenous demands for collective rights, on the one hand, and social and economic rights on the other hand. ${ }^{34}$

In addition to Bill C-21, the apology and the TRC have emerged as the most visible elements of the Harper government's First Nations policy, while it has noticeably ignored two particularly salient indigenous demands, to revive Kelowna and to sign on to the UN Declaration on the Rights of Indigenous Peoples. In fact, the government has taken a predictably neoliberal approach to economic development on reserves, focusing on resource exploitation and small business development rather than the priorities identified by First Nations themselves and laid out in the Kelowna Accord: education, housing, social welfare, and health. ${ }^{35}$ Current Indian Affairs minister Chuck Strahl has repeatedly rejected demands to endorse the Declaration. Fontaine has speculated that the government's rush to approve the human rights bill was a tactic to deflect criticism away from its decision to reject "indigenous rights". 36 At a reception after the apology Beverley Jacobs, head of the Native Women's Association of Canada, proposed that the apology would be more credible if the government approved the Declaration. Strahl responded by repeating the government's position that it prefers to work on practical matters at home rather than sign on to "flowery words" of a declaration of principles. ${ }^{37}$

\footnotetext{
${ }^{33}$ See Appendix 1 for a fuller description of the Settlement Agreement.

${ }^{34}$ In the South African context, Mahmood Mamdani has argued eloquently that the legacy of colonialism concerned social suffering, not primarily individual human rights violations. Transitional justice, he argues, should be about the provision of social and economic rights, not truth and reconciliation. Mahmood Mamdani, "Beyond Settler and Native as Political Identities: Overcoming the Political Legacy of Colonialism," Comparative Studies in Society and History 43, no.4 (2001). It is relevant to bring his analysis into the context of transitional justice for aboriginal peoples because the perception of a trade-off, and of a bifurcation of political claims and strategies, bedevils indigenous politics in many parts of the world, including Canada. The background to the Canadian apology and TRC show how governments may try to present human rights as an alternative, rather than a complement, to social and economic rights.

${ }^{35}$ From the Indian and Northern Affairs Canada official ministry website. www.ainc-inac.gc.ca/ai/mr/nr/ja2009/nr000000189-eng.asp

36 “AFN Chief Expresses Concern About Government Efforts to Rush Human Rights Legislation Without Proper Consultation," AFN press release, July 242007 www.afn.ca/article.asp?id=3712

37 "Leaders hope apology will curb prejudice; Truth and reconciliation. 'Real and lasting forgiveness must be earned" The Gazette, Montreal, Quebec. June 14, 2008: A14
} 
In such an adversarial political environment, aboriginal leaders may try to use transitional justice to open up political space, and to press further demands. The success of transitional justice in addressing indigenous demands for justice may depend therefore on its capacity to animate politics, and political accountability, beyond its limited mandate. There are three ways it might accomplish this aim. First, transitional justice measures may extend their definitions of injustice to include not only individual harms suffered by former students themselves, but also collective and cultural harms suffered by aboriginal communities, languages, and cultures. While acknowledging the harms done to individuals, they may place significant weight on collective and intergenerational harms, and try to change dominant conceptions of who suffered the injustice (whole populations, not individual students) and what counts as an injustice (loss of culture and language, not only physical or sexual abuse). Because the primary aim of the residential schools was to extinguish aboriginal language and culture, with explicit and intended intergenerational effects, such harms are clearly identifiable as a major and lasting component of the legacy of the residential school system.

Survivors and Aboriginal leaders have insisted that the residential school system caused harm to communities as a whole. When the children were taken away, it affected parents, aunts, uncles, and grandparents, and not only the children themselves. Many customs and traditions could not be practiced without the children, and the loss of the children undermined family and communal life. The Residential Schools policy was explicitly intended to destroy Indian language and intergenerational cultural transmission, and to a great extent it succeeded. Loss of language and culture, described explicitly as communal rather than individual losses, were repeatedly entered as evidence in the residential schools cases.

Aboriginal survivors have also tried to resist the logic of "individualizing" the harm of residential schools by insisting on the forward-acting effects of the schools on subsequent generations. Research has shown that residential school survivors often suffer from drug and alcohol addictions, depression, higher rates of suicide, and poor relationship and parenting skills. Many are not only victims, but also perpetrators of sexual and physical abuse. The children and other family members of Residential School survivors suffer the continuing effects of their parents' experience in the schools. They also suffer because parents have been unable to transmit their own language, culture, and moral framework to their children. It is to some extent the children of residential school survivors who have inherited the real long-term impact of the schools - the loss of culture and language, substance abuse, and family violence. ${ }^{38}$

In response to this intergenerational conception of harm, the Settlement Agreement allocates $\$ 125$ million for "community healing." This money has been allocated to the Aboriginal Healing Foundation, which is supposed to use it to fund "eligible projects" that:

\footnotetext{
${ }^{38}$ The intergenerational effects of trauma have been well-documented, in particular in studies of children of Holocaust survivors. IJzendoorn, Marinus H. van "Are children of Holocaust survivors less well-adapted? A metaanalytic investigation of secondary traumatization" Journal of Traumatic Stress 16,5 (2003) 459-469 2003; Halasz, George "Children of child survivors of the Holocaust : can trauma be transmitted across the generations?" Pro Memoria 21 (2004) 45-49 2004; Brom, Danny, “A controlled double-blind study on children of Holocaust survivors” Israel Journal of Psychiatry 38,1 (2001) 47-57 2001
} 
address healing needs of Aboriginal People affected by the Legacy of Indian Residential Schools, which could include the intergenerational impacts. Under the terms of the Settlement Agreement, eligible projects (a) focus on prevention and early detection of the effects of the Legacy of Indian Residential Schools, including the intergenerational impacts on all generations; (b) include elements of research and of capacity building for communities, including Communities of Interest, to address their long-term healing needs; (c) include, where and when possible, and depending on local needs and circumstances, a holistic approach including medial and traditional methodologies; (d) address special needs of segments of the population, including those of the elderly, youth and women; and (e) be based on a community healing approach designed to address needs of individuals, families and communities, which may include Communities of Interest. ${ }^{39}$

A second way to extend the scope of transitional justice beyond individual survivors alone is through attention to the potential danger that individual compensation and a truth commission that focuses on the experience of survivors will generate divisions between survivors and aboriginals who were not sent to Residential Schools. Roughly ten percent of the aboriginal population of Canada has received compensation for their residential school experience, which means that roughly ninety percent are left out of the transitional justice framework, have received no apology, and are unlikely to participate in the main events of the TRC. ${ }^{40}$ Part of the legacy of the Residential Schools is fractured communities. Transitional justice must be careful not to reproduce that outcome.

The TRC must therefore take seriously the claim that harms were done to families and communities as a whole, not only to individual survivors. Commissioners may choose to translate their mandate broadly, to reach out to aboriginals who are not school survivors, and to support the "community healing" dimension of the Settlement Agreement with outreach programs intended to draw whole communities, and not only survivors, into a common dialogue.

One way to do so may be through reconciliation-a concept that is under-specified in the context of the Canadian TRC. ${ }^{41}$ The Truth and Reconciliation Commission is clearly tasked with providing a forum for survivor testimony, and for documenting and archiving such testimony. Along with an independent research component, this dimension of the TRC has been identified as fulfilling the mandate for uncovering the truth of the residential schools policy and experience.

\footnotetext{
${ }^{39}$ Indian Residential Schools Settlement Agreement, Schedule M, Funding Agreement between the Aboriginal Healing Foundation and Canada, May 8, 2006, available at www.residentialschoolsettlement.ca/Schedule_M.pdf. ${ }^{40} 94,000$ people applied for the common experience payments, and 1.3 million people reported at least some aboriginal ancestry in the 2001 census.

www12.statcan.ca/english/census01/Products/Analytic/companion/abor/canada.cfm

${ }^{41}$ When Justice Harry LaForme resigned as TRC Comissioner in September 2008, he cited differences between himself and the other commissioners over whether the TRC should focus on truth, as they proposed, or on reconciliation, as he insisted. The substance of this difference has never been fleshed out, and it remains very unclear what LaForme meant by reconciliation, and how his vision differed substantively from that of his colleagues. Nevertheless, his claim and resignation have put the issue of reconciliation on the table in potentially fruitful ways.
} 
How the TRC will achieve the complementary task of reconciliation is left unclear in the TRC mandate, but it is worth considering seriously as "reconciliation" could provide a bridge between "survivors" and "non-survivors," and not only between aboriginals and non-aboriginals. One way to do both would be to try to use the TRC to organize and mobilize aboriginal political participation, taking advantage of the fact that the truth commission will hold hearings and commemorations in hundreds of small communities across Canada. This government-funded odyssey presents opportunities for information dissemination, political education, organization, registration, and mobilization among a population that is normally fractured, un-informed or misinformed, and politically apathetic.

The concept of reconciliation could be mobilized to rebuild capacity and institutions for political participation at three distinct levels of engagement: self-government, aboriginal political leadership, and Canadian politics. One way to reach beyond survivors alone is to invest in local capacity building to strengthen indigenous self-government. Such a project might be conceived as a springboard for mobilizing an aboriginal political voice and reinvesting First Nations in Canadian political life, building trust in the democratic process and democratic institutions. If the commission can reach beyond survivors to promote local capacity-building, and to invest aboriginal peoples in Canadian politics, it may be able to activate multiple tendrils of reconciliation.

Third, indigenous leaders could try to extend the concept of transitional justice beyond the residential schools policy alone, to open up a debate on historic injustice more broadly. To some extent, the Indian Residential Schools Settlement Agreement has already accomplished one such move, by negotiating a "common experience payment" for all residential school survivors. Previous frameworks for addressing government responsibility for the residential school system allocated compensation only to those former students who suffered sexual or serious physical abuse at the schools. Jane Stewart's 1998 Statement of Reconciliation expressed regret not for the residential school system as a whole, but specifically to those students who had suffered physical or sexual abuse in the schools. Such a paradigm sustains the myth that the system itself was faultless by acknowledging only harms perpetrated by particular individuals (a few bad apples) within the system. A common experience payment that offers compensation to anyone who went through the residential school system, regardless of their experience within the system, sustains a more far-reaching critique of the system as a whole.

Aboriginal leaders may be able to push a transitional justice framework even further, to demonstrate that the residential school system was itself part of a larger web of racist and oppressive government policies that have structured and limited indigenous life and life chances. The residential school system was not an aberration in Canadian government policy toward First Nations. The system was of a piece with other racist and discriminatory practices that have structured aboriginal life and life chances for the past three hundred years, mostly under the sheltering umbrella of the Indian Act. The government's acknowledgement of the injustice and cruelty of the residential school system offers an opening that aboriginals could use to highlight the injustices of other government policies, and the almost ludicrous effrontery of offering an apology for the residential school system alone, in light of the apocalyptic damage and harm the 
colonial and Canadian governments have perpetrated against aboriginal peoples. To the extent a transitional justice paradigm supposes the existence of historic injustice, and implies that states have an obligation to redress such injustice, it may open space for a much broader conceptualization of the actual injustices post-colonial governments may be held responsible for.

\section{The temporal implications of "transitional" justice}

The first sentence of the "Mandate for the Truth and Reconciliation Commission" states: "There is an emerging and compelling desire to put the events of the past behind us so that we can work towards a stronger and healthier future."

The scope of transitional justice is not only limited spatially, to a particular segment or type of injustice, but also has the potential to be contested temporally. For the government, one goal of transitional justice is to draw a line through history, emphasizing that it takes responsibility for government abuses that are nevertheless firmly in the past. It thereby underlines the difference between the past and the present, and the distinction between present and past policy. It hopes also to bring an end to recriminations that keep it morally on the defensive. Such government initiatives as apologies, truth commissions, and reparations are designed in part to allow the government and the dominant (settler) society to say finally to aboriginal peoples "OK, now we're even." The "transition" is to an even playing field in which the government can no longer be held accountable for past wrongs.

For indigenous leaders, transitional justice is not a wall, but a bridge. Aboriginal peoples will have an interest in using apologies, compensation, and truth commissions to draw history into the present, and to draw connections between past policy, present policy, and present injustices. Indigenous peoples may wish to extend new conceptions of historical wrongs to demonstrate that certain present policies re-inscribe historical injustices and relations of oppression. It has taken many years for non-aboriginal Canadians to recognize and acknowledge that the residential school system was racist, abusive, and fundamentally wrong, not only in its practice but in its intent. Indigenous leaders may hope to use the moment of transitional justice to push this cognitive transformation, to question the legitimacy of present policies and to draw conceptual links between present and past policies. Whereas the government may try to use transitional justice to signal a break with the past, indigenous activists may try to use the past as a way to critique the present. For them, transitional justice is effective to the extent it links the past with the present. The "transition" is to a relationship in which connections between past and present are firmly acknowledged, and in which the past guides present conceptions of obligation.

The tension between government and indigenous conceptions of how transitional justice affects the relationship between past and present is evident in reparations, the TRC, and the apology. The IRSSA provides "at least $\$ 1.9$ billion" for "common experience" payments to former students who lived at one of the residential schools. Each student is entitled to $\$ 10,000$ for the first year, or part of a year, that s/he spent at school, and $\$ 3,000$ for each additional year. Common experience payments are not taxable. Family members of students are not eligible for compensation. Students who suffered sexual or serious physical abuse may additionally go through an "independent assessment process" to determine the extent of their abuse and, therefore, the extent of their compensation. As the public notice explaining the residential school 
settlement states, "Awards are based on a point system for different abuses and resulting harms. The more points the greater the payment." 42 The "independent assessment process" replaces the alternative dispute resolution process previously in place. By July 2008, the government had received 94,085 applications for the Common Experience Payment and issued payments to 66,232 survivors. Payments have been somewhat lower than anticipated, primarily because of problems with documenting attendance, and a significant number of cases are being contested. ${ }^{43}$

Once the settlement agreement was reached, former students of residential schools faced a stark choice. By filling out a claim form and accepting compensation, former students gave up the right to go through the courts in the future. The public notice of the settlement states, "Former students - and family members - who stay in the settlement will never again be able to sue the Government of Canada, the Churches who joined in the settlement, or any other defendant in the class actions, over residential schools." ${ }^{44}$ Former students who wished to retain the right to sue had to submit a form to "opt out" of the class action by August 20, 2007. The government included a clause in the agreement that stipulated that if 5,000 people opted out of the common experience payment the government could back out of the agreement altogether.

From the perspective of the government, the clear intent of the Settlement Agreement was to shut down the wave of litigation that propelled the issue of residential schools onto the political stage and kept the Canadian government on the defensive for more than 15 years. If the Settlement Agreement did not accomplish that goal, the government explicitly, and legally, secured the right to back out of the agreement. Nevertheless, the agreement did accomplish that goal. "With only 340 people opting out by the 2007 deadline, the Settlement Agreement has effectively corralled residential schools claims into a standardized compensation process." ${ }^{45}$ In 2006, there were roughly 12,000 claims lodged against the churches and the government; these were largely resolved by the Settlement Agreement. ${ }^{46}$

In a context of transitional justice, there are benefits to such a move. A compensation package limits the amount of compensation an individual can receive, but offers reparation more broadly to all those affected. From the perspective of compensation alone, a widely disbursed "common experience payment," supplemented by additional payments for abuse, can be seen as fulfilling a commitment to justice. Pablo de Grieff makes the case that a disparity in the amount of an award does not necessarily produce an injustice to the extent that reparations programs obviate other costs associated with litigation: long delays, high costs, cross-examination, gathering evidence, and the possibility of an adverse decision. ${ }^{47}$ AFN and other residential school survivor groups have pointed explicitly to these costs when they endorse the compensation package included in the Settlement Agreement.

\footnotetext{
${ }^{42}$ www.residentialschoolsettlement.ca

${ }^{43}$ ICTJ Website "Where we work: Canada" www.ictj.org/en/where/region2/513.html

${ }^{44}$ www.residentialschoolsettlement.ca/summary_notice.pdf

${ }^{45}$ Linda Popic, “Compensating Canada's Stolen Generations” Indigenous Law Bulletin December/January 2008

Volume 7, Issue 2,15

46 Ibid.

${ }^{47}$ Pablo de Grieff, The Handbook of Reparations, 2006, pg.439
} 
Transitional justice nevertheless normally conceives such initiatives as criminal prosecutions, truth commissions, reparations, and memorialization as complementary: "to be effective transitional justice should include several measures that complement one another. Truth-telling, in isolation from efforts to punish abusers and to make institutional reforms, can be viewed as nothing more than words. Reparations that are not linked to prosecutions or truth-telling may be perceived as "blood money" - an attempt to buy the silence or acquiescence of victims." 48 The Settlement Agreement has the potential to be perceived in this way precisely because it offered compensation only in exchange for an end to court battles.

Indeed, if reparations and truth commissions are offered as an alternative to law, they may even be the source of renewed grievance. ${ }^{49}$ To the extent that transitional justice is perceived as a way of closing off legal avenues of redress, and of insulating the government (and churches) from the law, some of its reconciliatory potential may be squandered. The mandate of the TRC reinforces this trade-off between law and transitional justice, making clear that the truth commission is not empowered to "hold formal hearings, act as a public inquiry, or conduct a formal legal process." The truth commission does not possess subpoena powers, and the commission cannot make any findings or express any conclusion or recommendation regarding the misconduct of any person. Nor shall the commission "name names in their events, activities, public statements, report, or recommendations, or make use of personal information or statements made which identify a person," neither will it "record the names of persons so identified" when they are named in testimony. These limitations make the Canadian TRC significantly weaker than many other truth commissions, for example in South Africa. The TRC is tasked with eliciting and documenting survivors' accounts of their Residential School experience, which may inscribe a "survivor narrative" into Canadian history and act as a bridge to the present. Nevertheless, the TRC is also part of the process of putting an end to the government's legal liability.

The apology has also been used to draw a line through history. On June 11, 2008, Canadian Prime Minister Stephen Harper stood in the House of Commons and issued a statement of apology to victims of the Residential School system (see appendix 2). Against the backdrop of other Conservative government policies toward First Nations, the Harper Apology is somewhat anomalous. The Conservative government firmly resisted demands for an apology until at least August 2007. In March 2007, then Minister of Indian Affairs Jim Prentice insisted that an apology would not accompany the TRC and the victims' reparations package ordered by the

\footnotetext{
${ }^{48} \mathrm{http}$ ://www.ictj.org/en/tj/. Some survivors do in fact appear to view compensation through this lens, suggesting that the offer of money further compromised their integrity. The fact that so few survivors opted out of the compensation package should not be taken as evidence that most people are satisfied with it, or that compensation has put an end to grievance.

${ }^{49}$ A "lump sum" payment can also be challenging for receiving communities, creating divisions among beneficiaries and non-beneficiaries, including within families and extended families. In Canada, the lump sum payments have already been linked to suicides, a rise in substance abuse, and predatory marketing practices. "Aboriginal settlements bring woes of their own: Abuse payments trigger trauma, linked to deaths," www.ottawacitizen.com/Aboriginal+settlements+bring+woes+their/1217628/story.html
} 
court in the Indian Residential Schools Settlement Agreement because it was not required by the agreement. He also suggested that no apology was necessary, since "fundamentally, the underlying objective had been to try and provide an education to aboriginal children"- $-\mathrm{a}$ benign motive, in his mind, that differentiated this case from that of Maher Arar's torture in Syria and the head tax paid by Chinese immigrants in the first half of the twentieth century-two other policies for which Harper had apologized in his first two years in office." ${ }^{50}$ Prentice and Harper reportedly believed that, if there was to be an apology, it should come after the TRC issued its final report_-after the evidence was in, in other words. ${ }^{51}$

Nevertheless, in April 2007, Liberal MP Gary Merasty moved a motion in the House of Commons calling on MPs to apologize, and the Tories voted in favor. On May 1, 2007 the House of Commons issued an apology, but the executive remained recalcitrant. Other MPs and the Indian Affairs Minister evidently weighed in with Harper and convinced him of two things. First, that an apology would help build trust and secure support for the First Nations initiatives the Conservatives hoped to advance. Bill C-44 was in front of the Aboriginal and Northern Affairs Committee in March through June of that year, and opposition committee members reported that they were under "considerable pressure" to pass the Bill. ${ }^{52}$ Second, residential school students were dying at the rate of four per day, which would mean that many would not live to hear an apology at the end of the TRC mandate in five years. In his Speech from the Throne, given at the opening session of parliament in October 2007, Harper promised an apology. 53

According to Indian Affairs Minister Chuck Strahl, the wording of the apology was shaped in part by "ongoing consultations" between Strahl, the prime minister, and residential school survivors. Nevertheless, Harper faced criticism that indigenous leaders had not been sufficiently involved in drafting the apology. For example, the government refused to circulate a draft of the apology, despite requests from the Assembly of First Nations and the National Residential Schools Survivors Society. NDP leader Jack Layton warned that the Conservative government "run[s] the risk of that kind of paternalistic attitude of "we know best and First Nations will just have to accept what we dish out.", 54

In fact, in the weeks leading up to the apology, the AFN ran itself ragged trying to ensure that Harper would deliver an appropriate apology in the appropriate way. On one level, AFN leaders were probably concerned that the apology could be offered in such a way that it failed to satisfy the needs of survivors to hear the government accept responsibility and express regret, and yet satisfied the government's obligation to issue an apology. Even if the apology was a poor one, it

\footnotetext{
50 "Why to apologize for the residential schools," The Globe and Mail, March 28, 2007; "Mounting sense of urgency was apology's catalyst," The Globe and Mail, June 13, 2008, A4

${ }^{51}$ www.harperindex.ca/ViewArticle.cfm?Ref=0022 May 16, 2007

52 "AFN, Opposition Stiffen Resistance to Bill C-44, Legal Experts Cite Grave Problems with Bill" e-notes from four arrows@ canada.com 9 June 2007 Edition www.gatheringplacefirstnationscanews.ca/Governance/Rarihokwats/prentice\%20on\%20kelowna.pdf

53 "Mounting sense of urgency was apology's catalyst," The Globe and Mail, June 13, 2008 A4

54 "Plan for residential-school apology criticized," The Globe and Mail, June 6, 2008, A4; "Native groups shut out of residential schools apology" The Canadian Press, 6 June 2008 A5
} 
would probably be the last one residential school survivors would get. The AFN hoped to make sure the moment was not squandered. ${ }^{55}$

Several aboriginal groups also complained that the government had not funded travel for school survivors who wished to witness the apology in person. As Strahl told reporters, "We're not going to pay for thousands of students to fly to Ottawa." Roughly 100 aboriginals, mainly board members of school survivor groups, were flown to Ottawa at government expense. ${ }^{56}$

A few hours before the apology, Conservative MP Pierre Poilievre said on an Ottawa radio show, "Now, along with this apology comes another $\$ 4$ billion in compensation for those who partook in the residential schools over those years. My view is that we need to engender the values of hard work and independence and self-reliance." His outburst generated a torrent of email responses, much of it accusing him of undermining the apology. Although Poilievre issued his own apology in the House of Commons the next day, fully retracting his remarks, for many, his comments revealed the cynicism of the Harper apology against the backdrop of the Conservative government's otherwise regressive policies toward First Nations. ${ }^{57}$

Most Residential School survivors and First Nations leaders nevertheless endorsed the apology, and approved of its wording. Many were pleased that Harper had used the term "survivor" to refer to former students, because Ottawa has long resisted the terminology employed by most groups of former residential school students. Harper also acknowledged the damage that schools had caused to indigenous communities and cultures, and not only to individual students, and to the capacity of First Nations to reproduce and pass down their languages and traditions. Harper said explicitly "We are sorry," and he was clear about what the government was sorry for. He also, at least metaphorically, transferred responsibility for the residential schools experience from indigenous communities to the government. Specifically, Harper said, "The burden of this experience has been on your shoulders for far too long. The burden is properly ours as a government, and as a country." He concluded by endorsing the Truth and Reconciliation Commission, and expressed hope in its ability to "educate all Canadians" about the residential school system and to forge a new relationship between aboriginal and other Canadians. Most indigenous commentators agreed that the text and tone of the apology was sincere.

The apology included both of the dimensions that de Grieff has identified as important components of reconciliation: the acceptance of responsibility and the expression of regret. De Grieff argues that apologies act most importantly to affirm common norms and values. The

\footnotetext{
55 “AFN Chief Visits Trent” November 24, 2008 Www.trentarthur.ca/index 2 .php?option=com_content\&do_pdf $=1 \& i d=1025$

The AFN's concern over the wording, timing, and delivery of the apology can also be attributed to an interest in using the apology to create a legacy for Fontaine. As the elected leader of the Assembly of First Nations, Fontaine is able to take credit for government initiatives that take place while he is in office. When such initiatives fail, as they did for example in the case of the Kelowna Accord, his legacy suffers a setback. In particular because of his role in negotiating the Settlement Agreement, Fontaine's reputation is now tied to the success of the apology, compensation, and the TRC.

56 "Plan for residential-school apology criticized," The Globe and Mail, June 6, 2008, A4.

57 "MP retracts radio remarks," The Globe and Mail, June 13, 2008, A4 "Next step: more accountable and transparent native governments," The Globe and Mail, July 28, 2008, A13
} 
apology acknowledged that a norm was violated, and the acknowledgement re-established a common moral ground. In this case, Harper acknowledged that indigenous judgments about the wrongness of residential schools were right after all, and the judgment of the government, and of the churches, and of the dominant society, was wrong. Many residential school survivors focused on this dimension of the apology. They insisted that the Prime Minister had to go beyond saying "We are sorry," and admit that they were wrong. ${ }^{58}$ In his speech, Harper said three times that the government's residential school policy was wrong, and many indigenous people claimed to draw strength from that admission. AFN leader Phil Fontaine explained, for example, "For first nations, it will restore our dignity because it will say we were unjustly wronged as a people over generations simply because of who we were," he said. "The apology will affirm that we are as good as anyone." 59

In his response to the prime minister's apology, read, after protracted negotiations, from the floor of the House of Commons, Fontaine said, "Never again will this House consider us the Indian problem just for being who we are. We heard the Government of Canada take full responsibility for this dreadful chapter in our shared history. We heard the prime minister declare that this will never happen again. Finally, we heard Canada say it is sorry. Brave survivors, through the telling of their painful stories, have stripped white supremacy of its authority and legitimacy. The irresistibility of speaking truth to power is real. Today is not the result of a political game. Instead, it is something that shows the righteousness and importance of our struggle." 60

A surprising number of non-indigenous Canadians were also aware of, and supported, the apology. In a survey conducted between June 11 and 13, 2008, 83 percent of respondents were aware of the apology to residential school students. Among those who were aware, 71 percent agreed or agreed strongly that the government should apologize, and only 18 percent disagreed or strongly disagreed. Political affiliation nevertheless distinguished respondents, with only 66 percent of Conservatives expressing support for the (Conservative government's) apology, compared with 75 percent of Liberal voters and 82 percent of NDP voters. One third of respondents said they were left with a more favorable view of government, and the apology had the greatest positive impact among young people. ${ }^{61}$

Expectations about what will come of the apology nevertheless diverge significantly. For many non-indigenous Canadians, the apology was meant to close a chapter of Canadian history. By accepting guilt, many expect to be able to move on, to draw a line that separates the present from a shameful and unfortunate past. The point of an apology, many believe, is to put the past behind us. In our personal lives we often use apologies to shut down recrimination and take back some of the moral ground we have lost by our actions. Many people expect an official state apology to do the same. As one columnist wrote, "It is much to be hoped that native Canadians accept the apology in the spirit in which it was offered and now move on, lest a grievance culture becomes

\footnotetext{
${ }^{58}$ Elise Stolte, "PM's apology must go beyond sorry, aboriginals say; Healing for community rests on Ottawa taking responsibility for its past," Edmonton Journal, June 9, 2008, A1.

59 Anne McIlroy and Bill Curry, "97 years later, apology at last,” The Globe and Mail, June 9, 2008, A1.

60 "Canada Apologizes," Globe and Mail, June 11, 2008 A1. Harper initially refused to allow a response from the floor, and invoked parliamentary rules to prevent it. But AFN staffers were able to identify a set of procedural rules that allowed a response under such circumstances, and the leaders of the opposition parties also favored responses.

61 "School-abuse apology widely backed," The Globe and Mail, June 14, 2008 A4
} 
so deep-rooted that they are unable to transcend it and self-identify with victim status forevermore." 62

Former Conservative party campaign manager Tom Flanagan expressed a similar sentiment when he noted, with indignation, that indigenous leaders expected the apology to lead to something more. "The Conservative government," he said, "is now being reminded of the truism that one thing leads to another. The aboriginal industry sees the government's re-apology for Indian residential schools as a sign of weakness, leading to a wave of demands to resuscitate the Kelowna Accord." Instead, he insists, the apology should have no effect on the government's First Nations policy. "At this juncture, it is critical for the government not to get knocked off its own agenda." Indeed, what Flanagan proposes as a next step is that First Nations reform their own governments to demonstrate more transparency and accountability. Apparently, the government's apology should lead to a quid pro quo-some kind of acknowledgement that First Nations have been complicit in their own misfortune, and also bear responsibility. ${ }^{63}$

For most indigenous leaders and residential school survivors, however, this is not the obvious next step, although the presumption that the apology implies further action is practically universal. As Grand Chief Edward John wrote on the eve of the apology, "An apology alone is not reconciliation. An apology cannot undo history." "64 Mary Simon, president of the Inuit Tapiriit Kanatami, has reiterated that sentiment, insisting "that real and lasting forgiveness must be earned. It will be forthcoming only when it becomes clear that the government is willing to act." ${ }^{\text {"65 }}$ AFN leader Phil Fontaine consistently invokes the apology as a source of legitimacy and momentum, implying not only that something must follow from the apology but that something must follow quickly. When Justice Harry La Forme resigned as chair of the TRC commission in October 2008, Fontaine issued a statement that said, among other things, "We are prepared to act quickly with due regard to Survivors, but we must not lose the momentum that was created by the Apology of June 11th. We cannot afford to be distracted from the purpose and intent of the TRC and its work that is vital to the future First Nations-Canadian relations in this country.",66

In the months since the apology, Fontaine and others have pointed repeatedly to the large gap between the rhetoric and intent of the apology and the TRC and the Conservative government's continued recalcitrance on social welfare policies toward First Nations. At a July 2008 meeting of premiers, Fontaine said the apology and the work of the commission were very important for the survivors and for the country. He added, however, that concrete actions were needed to back the rhetoric. In his statement, he pointedly recalled that the Conservatives had scuttled the Kelowna Accord, adding that "First Nations want more funding for education, training, and skills development for native children. What we want to see from the Council of the Federation is continuous support to fill the gap of quality of life between Canadians and us."

\footnotetext{
${ }^{62}$ John Ivison, “A good day for Canada, and for Stephen Harper,” Victoria Times Colonist, June 12, 2008, A14.

63 "Next step: more accountable and transparent native governments," The Globe and Mail, July 28, 2008 , A13

64 "Break from the past; What's expected from the residential schools apology," Vancouver Sun, June 11, 2008 , A15

65 "Leaders hope apology will curb prejudice; Truth and reconciliation. 'Real and lasting forgiveness must be earned"” The Gazette, Montreal, Quebec, June 14, 2008: A14

66 "National Chief Issues Statement on Resignation of Justice Harry LaForme as the Chair of the Truth and Reconciliation Commission," October 21, 2008 www.afn.ca/article.asp?id=4254
} 
The sincerity of apologies cannot be judged by tone alone, and will inevitably be seen in the context of "what comes next." Although indigenous reactions to the apology were very positive in the immediate aftermath, the sense of vindication, and of the beginning of a new era, dissipated within months as indigenous people began to note that the apology was not followed by any tangible commitment. For many, a commitment to reconciliation signals a commitment to more concerted efforts, and greater funding, for indigenous initiatives. Reconciliation, many aboriginal leaders believe, should be signaled by government responsiveness to aboriginal needs and demands. But there is no evidence of a "new dawn" in the relationship between indigenous and non-indigenous Canadians, and the more the evidence is missing, the more isolated and irrelevant the apology appears. One way to interpret the disappointment that has followed so quickly on the heels of the apology is that First Nations saw it as a beginning, whereas the government may have seen it as an end.

One of the most conspicuous connections between the residential school system and present government policy toward First Nations is child welfare. By some estimates, the Canadian Child Welfare system is currently responsible for roughly 27,000 aboriginal children who have been removed from their homes into protective custody. According to a report issued by the AFN, there are currently more than three times as many aboriginal children in the care of child welfare agencies as there were in residential schools at the height of the system. Whereas one out of every 200 children in the general population is placed in the care of child welfare, one out of every ten aboriginal children have been removed from their homes by child welfare agencies. ${ }^{67}$ Most children are removed from their families because they suffer from "neglect" associated with substance abuse. Many of those substance abusing parents are residential school survivors.

Once removed, the relationship between parents and children is remanded to the courts. With inadequate understanding of the legal system, inadequate legal counsel, and limited or no translation services, court proceedings often terminate parental rights. Responsibility and accountability rest with the mandated child welfare and legal systems and away from First Nations families and communities.

Aboriginal peoples often draw connections between the residential school system and present child welfare policies that remove Aboriginal children from their homes and communities. In November 2008, 60 First Nations residents of Regina protested outside a court hearing in which grandparents were attempting to regain custody of a five year old girl who had been removed from her home by child welfare services. The protestors compared this custody battle to the battle First Nations people faced in the past with the residential school system. As the organizer explained, "It's been done in history... where they took the kids out of the home and put them in the school," she said. "That caused a lot of problems with addictions and all the social ills because they couldn't take care of their families. The government apologized for that. They said they were sorry and they compensated, and now it's starting over again, but this time...in a courtroom." 68

\footnotetext{
${ }^{67}$ Assembly of First Nations, "Leadership Action Plan on First Nations Child Welfare" 2006 www.afn.ca/misc/afnchild.pdf p.1

${ }^{68}$ Derek Putz, "Case a flashback to residential school system: protestor," Leader Post, November 20, 2008, 1
} 
First Nations seek jurisdiction over aboriginal child welfare. Child welfare theorists have identified a set of best practices for aboriginal children, including community-based intervention that empowers the community-family, friends, and neighbors - to be involved in decisions about the well-being of children in their community. In Northern Manitoba, one First Nations Child and Family Service Agency has implemented a family welfare program that operates outside of the regular child welfare and court systems, using traditional peacemaking methods and family mediation. The program brings together family, extended family, community members, Elders, social workers and community service providers in the resolution of child protection concerns through the use of properly trained Okweskimowewak (family mediators). ${ }^{69}$ The program explicitly operates outside of the provincial legal system, and attempts to resolve child welfare issues using Cree norms and laws.

By linking the past with the present, a transitional justice framework may be used to illuminate the subtle, and not so subtle, racism and cultural bias that continues to taint the relationship between the Canadian government and aboriginal families. To the extent child welfare policy can be linked to the residential school system, even conceptually, if not institutionally, it may fall under the mandate of transitional justice. Through the child welfare system, the past is visited on the present. Could the TRC, which has a significant research component, include research on First Nations child welfare policy? The transitional justice framework may be used to push the government to implement the best practices that have already been identified, including community-based intervention using aboriginal laws, and mediation as an alternative to the courts. Child welfare may be one specific area in which transitional justice can be deployed to shine critical light on the present through the lens of the past.

\section{Sovereignty and legal pluralism}

The issue of sovereignty may importantly distinguish attempts to use transitional justice measures in post-authoritarian and post-conflict societies from the use of transitional justice to address historic injustices against indigenous peoples in societies that are not undergoing transition. States use transitional justice measures to make amends for human rights violations that they commit against their own citizens. The transitional justice framework is distinct from a human rights framework to the extent it balances demands for criminal prosecutions against a perceived need to sustain democratic institutions in a transitional setting where such institutions may be fragile. ${ }^{70}$ Against this conceptual backdrop, it should be clear that using transitional justice measures in the absence of transition or regime change is of more than semantic concern. Transitional justice measures are designed in large part to reinscribe a common national identity, legitimate the government, and to re-establish the moral authority of state sovereignty-all of this, without any transition.

Even governments that have not undergone transition may be able to employ the conceptual architecture of transitional justice to reinforce the sovereign authority of the state over its indigenous population. Apologies highlight the ways in which the state failed a segment of its own population by failing to treat its citizens equally. Truth commissions aim in part to rewrite

\footnotetext{
${ }^{69}$ Joe Pintarics and Karen Sveinunggaard, "Meenoostahtan Menisiwin: First Nations Family Justice, Pathways to Peace," The First Peoples Family and Child Review 2, No. 1 (2005), 67

${ }^{70}$ Paige Arthur, "How 'Transitions' Re-shaped Human Rights: A Conceptual History of Transitional Justice"
} 
the history of a nation, and to weave the indigenous historical experience into a new common national narrative. Truth commissions also aim to achieve reconciliation, to restore trust in government, and to include indigenous people in the creation of collective memory and history. Transitional justice measures aim to "promote confidence in the political arrangements and restore to citizens full membership in society." "71 They are about integration and the assertion of a common national identity.

Yet one of the historic injustices that lies at the heart of indigenous identity is loss of sovereignty. Indigenous peoples are defined in part by the fact that their sovereignty was not recognized by colonial powers that appropriated territory and sovereignty under the doctrine of terra nullius. Indigenous identity is premised on a common experience of dispossession, and indigenous politics draws its own legitimacy from the illegality of that usurpation of sovereignty. The demand for territorial self-government, which challenges the sovereign authority of the state, has emerged as the central defining claim of the international indigenous rights movement. ${ }^{72}$

The use of a transitional justice framework could undercut the conceptual and legal connection the indigenous rights movement has drawn between the historical loss of sovereignty and the contemporary political presence of aboriginal peoples. It could, as a result, practically limit their capacity to make some of the claims - to self-government and territorial autonomy — that define the indigenous rights movement. Indigenous leaders have sought to resist the legitimating function that transitional justice performs on behalf of the state.

But they do so in a careful balancing act. Indigenous peoples also make other demands, demands that do rely on a presumption of state sovereignty, and that rest on the fact that aboriginal populations have been excluded from many of the social, economic, and political benefits of citizenship. Indigenous political claims derive not only from a history of forced inclusion, which has engendered demands for self-government, but also from exclusion, which has led to demands for full-social, economic, and political—rights in citizenship. To the extent they hope that transitional justice measures and rhetoric can animate these other claims, indigenous leaders may welcome government willingness to acknowledge a historical debt that also implies present obligations.

Indigenous demands for such transitional justice measures as apologies and truth commissions highlight the emotional and psychological complexities of the history and relationship between indigenous peoples, non-indigenous citizens of the same state, and the government. Indigenous demands for recognition and acknowledgement are tempered by simultaneous claims to sovereignty. Indigenous demands for truth-telling stem in part from a desire to inscribe their own historical experience in the history of the nation, while nevertheless maintaining a separate identity. For indigenous peoples, one aim of truth-telling, apologies, and reparations is to strengthen communities and self-governing capacities that were undermined by residential schools and other racist government practices.

\footnotetext{
${ }^{71}$ Malamud Goti, “Trying Violators of Human Rights," in State Crimes, 81-82 (drawn from Arthur, p26)

${ }^{72}$ While it is true that not all indigenous peoples demand self-government, the demand is nevertheless the distinguishing feature and binding thread of the international indigenous rights movement. As an organizing principle of indigenous politics, it is an important condition of the political voice of the movement.
} 
The potential contradictions generated by addressing indigenous claims for justice through a transitional justice framework, and by the concept of reconciliation that sits at the heart of that framework, might be addressed by importing into transitional justice the conception of "reconciliation" already implicit in Canadian law. This concept of reconciliation is premised on recognition that First Nations were sovereign at all relevant moments in the formation of the Canadian state. Reconciliation entails balancing aboriginal sovereignty with the sovereignty of Canada. More specifically, the Supreme Court has interpreted reconciliation as an obligation to reconcile Canadian and aboriginal legal systems. ${ }^{73}$ Since 1977 and the entrenchment of s.35 in the Constitution, Canadian jurisprudence has "moved away from governance under the Indian Act towards the general principle of reconciliation which the Supreme Court of Canada has said is at the heart of aboriginal-Crown relations. ... what is being reconciled is the pre-existence of aboriginal societies, including their legal systems and their laws, with the assertion of Crown sovereignty.",74

The Canadian Constitutional conception of reconciliation appears to be a valuable resource for transitional justice in these settings--toward indigenous peoples, in the absence of regime transition. Transitional justice measures in Canada should take this concept of reconciliation into account, extending the institutional and rhetorical spaces where indigenous law may be applied and acknowledged. Truth and reconciliation commissions in particular might be sites in which indigenous conceptions of truth and reconciliation, along with indigenous structures and procedures for achieving truth and reconciliation, could be employed. Such a precedent could have legal-juridical and jurisdictional-implications that extend beyond the moment of transitional justice. The legal principle of reconciliation might be used to mitigate some of the ways that transitional justice could threaten aboriginal claims to autonomy in four ways.

First, one implication of reconciliation is negotiation among equals, which has been interpreted as a duty to consult that imposes on the Canadian government an obligation of good faith. In the context of transitional justice, such a duty could be held to mean that every aspect of transitional justice (the text and timing of the apology, the amount and extent of compensation, the mandate and staffing of a truth commission) should be negotiated between the government and aboriginal representatives. In Canada, this model was approximated when AFN leader Fontaine shortcircuited the Political Agreement offered by the government by bringing a class action suit against the churches and the Canadian government. The Indian Residential Schools Settlement Agreement was the result of negotiations among the three parties, leading to an out of court settlement that was approved, and is enforceable, by the court. Once the opt-out option was

\footnotetext{
${ }^{73}$ Supreme Court of Canada, Delgamuukw v British Columbia [1997] 3 SCR 1010 (Can); R v Van der Peet [1996] 2 SCR

${ }^{74}$ Louise Mandell, in oral testimony in front of the Standing House Committee on Aboriginal Affairs, June 5, 2007

"AFN, Opposition Stiffen Resistance to Bill C-44, Legal Experts Cite Grave Problems with Bill" e-notes from four arrows@canada.com 9 June 2007 Edition (no page numbers) www.gatheringplacefirstnationscanews.ca/Governance/Rarihokwats/prentice\%20on\%20kelowna.pdf See also Jeremie Gilbert, "Historical Indigenous Peoples Land Claims: A Comparative and International Approach to the Common Law Doctrine on Indigenous Title," International and Comparative Law Quarterly vol 56, July 2007 pp.583-612 (esp.pp.591-92)
} 
closed, the Canadian government was legally bound to the agreement; even if there is a change of administration, it will be held to its commitment.

Second, transitional justice may be especially well-equipped to deal with demands for legal pluralism. Truth commissions are already set up, in part, to do some of the work that court cases would do, most importantly to provide testimony, without some of the more onerous and adversarial characteristics of Western court proceedings such as rules of evidence, burden of proof, cross-examination, and expensive legal counsel. Truth and reconciliation commissions, in short, have already recognized the ways in which Western courts and legal norms are inadequate to the tasks of truth-telling and reconciliation.

Nevertheless, such commissions also leave open the question of what norms and procedures are appropriate to truth-telling and reconciliation, creating an institutional opening where indigenous law could step in. Public hearings can be conducted in a variety of different ways, and one possibility would be to conduct such hearings in accordance with the norms and procedures of indigenous laws. The mandate of the TRC empowers the commission to recognize "the significance of Aboriginal oral and legal traditions in its activities" in the exercise of its duties. ${ }^{75}$

Beyond offering visibility and status to indigenous legal systems, such practice could strengthen indigenous law itself. The TRC would engage tribal Elders and others familiar with indigenous law, and install their knowledge and frameworks at the center of the process. Incorporating indigenous law into truth and reconciliation processes will require funding for training in indigenous law. To the extent some aspects of indigenous law require community participation and consensus, it can enlarge the truth commission beyond residential school survivors to include whole communities. As a result, it may also expose indigenous peoples to legal systems that have grown unfamiliar through disuse and through interruptions in cultural transmission generated by the residential school system itself.

Indigenous laws may also advance substantively different conceptions of the harms that were generated, and the laws that were violated, by the residential school system. As a result, incorporating indigenous law into truth-telling might lead to substantively different constructions of truth, constructions that may be more true to indigenous conceptions of justice and injustice.

Indigenous law should also be consulted with regard to reparations and compensation. Current practices of compensation in transitional justice rely on common law damage principles that use actuarial standards derived from insurance compensation for assigning a monetary figure to particular harms. Indigenous law should be consulted in deciding whether victims should receive different amounts of compensation depending on the actual harms they suffered, and in deciding who actually counts as a victim. Compensation that targets individual residential school survivors, and produces a hierarchy of victimhood by assigning points and monetary value to different types and degrees of violation, may violate indigenous norms and laws regarding restitution. Transitional justice measures will fail in their transformative goals if they fail to

\footnotetext{
${ }^{75}$ Mandate for the Truth and Reconciliation Commission, Schedule N, 5
} 
include indigenous legal conceptions of violations, victims, and justice in decisions regarding the scope and structure of apologies, reparations, and truth commissions. ${ }^{76}$

Third, a transitional justice framework may open space for aboriginals to draw on international laws, conventions, and declarations that specifically address the rights of indigenous peoples, including ILO Convention 169 and the United Nations Declaration on the Rights of Indigenous Peoples. Even though Canada voted against the Declaration, the document was passed by the UN General Assembly, which means it has as much force in Canada as it does anywhere.

Because it is not a treaty or a convention, it is not binding on any country, but as a Declaration it is a statement of principles that could be drawn down into Canadian jurisprudence. How judges would respond is an open question, which remains to be tested. ${ }^{77}$ Transitional justice actors, including for instance TRC commissioners, could be proactive in clarifying the status of the Declaration in Canada and in creating opportunities to use and develop the principles of the Declaration in the work of the commission.

Finally, the Truth and Reconciliation Commission offers a significant opportunity to develop and extend the concept of reconciliation beyond the law, into the domains of history, politics, human capacity building, and cultural revaluation. Meaningful reconciliation will have to go beyond law alone. Reconciliation should involve rewriting Canadian history to include aboriginal narratives, not only about the residential school system but about the history of the nation more generally. Reconciliation will involve opening space and forging mechanisms that will promote aboriginal political voice and leverage. Reconciliation requires investing in aboriginal wellbeing and capacity building. Reconciliation will entail re-valuing indigenous languages and cultures, lost and degraded in part through the residential school system.

\section{Conclusion}

Context matters. Whether transitional justice measures will serve primarily to legitimate the status quo between post-colonial states, settler societies, and aboriginal peoples, or whether they will have transformational capacity, will depend in part on the political context in which they take place. In Canada, the apology and the Settlement Agreement have been used in part to limit aboriginal demands for social justice and constitutional transformation, and to reinforce the individual rights framework of the Conservative Party's aboriginal policy. Aboriginal activists have tried instead to leverage the moral obligation implied by the apology and the Settlement Agreement to extend the scope of state responsibility. Specifically, for instance, they hoped the apology would lead to the revival of the Kelowna Accord.

One implication is that when transitional justice measures are used 1) toward indigenous peoples, 2) in cases where there has been no regime transition, their success must be measured by their capacity to transform the playing field. It is not enough for them to perform the standard

\footnotetext{
${ }^{76}$ Some scholarly work has been done on indigenous ideas of justice, most of it focusing on indigenous beliefs in restorative, as opposed to retributive justice. Indigenous justice is often aimed at healing, and restoring the relationship between victim and perpetrator. This conception of justice is clearly compatible with many of the goals and principles emphasized in transitional justice. Rupert Ross, Returning to the Teachings: Exploring Aboriginal Justice Penguin Books, 2006; Dancing with a Ghost: Exploring Indian Reality, Butterworths, 1992

${ }^{77}$ I am grateful to Patrick Macklem for clarifying the status of the Declaration in Canada.
} 
functions of legitimation and national conciliation that they have been designed for in postauthoritarian and post-conflict situations. The apology and the Settlement Agreement must be made relevant beyond the issue of residential schools, and beyond the circle of residential school survivors. Specifically, for example, the TRC may put the AFN in a better position to challenge Canadian government policies with regard to child welfare. More generally, the transitional justice framework should be deployed to highlight the degree to which the residential school system was merely one prong of a much more widespread and comprehensive policy of aboriginal dispossession, exclusion, and forced assimilation, with continuing impact on aboriginal well-being, culture, physical and psychological health, wealth, and citizenship rights. The scope of Canadian government obligation toward its indigenous population extends far beyond the legacy of the residential school system.

\section{Appendix I}

\section{The Indian Residential Schools Settlement Agreement}

On May 10, 2006, the Government announced the approval by all parties of the IRSSA. The Government's representative, the Honourable Frank Iacobucci, concluded the IRSSA with legal representatives of former students of Indian Residential Schools, legal representatives of the Churches involved in running those schools, the Assembly of First Nations, and other Aboriginal organizations.

The IRSSA was approved by the Courts and came into effect on September 19, 2007. The IRSSA includes the following individual and collective measures to address the legacy of the Indian Residential School system:

Common Experience Payment

Upon application, a Common Experience Payment will be paid to every eligible former student who resided at a recognized Indian Residential School living on May 30, 2005, the day the negotiations were initiated.

The IRSSA stipulates that $\$ 1.9$ billion be set aside for the direct benefit of former Indian Residential School students. Subject to verification, each eligible former student who applies would receive $\$ 10,000$ for the first school year or portion thereof and $\$ 3,000$ for each subsequent year.

Truth and Reconciliation

A Truth and Reconciliation Commission will be established with a budget of $\$ 60$ million over five years. It will be mandated to promote public education and awareness about the Indian Residential School system and its legacy, as well as provide former students, their families and communities an opportunity to share their Indian Residential School experiences in a safe and culturally-appropriate environment.

The Truth and Reconciliation Commission will undertake a series of national and community events and will establish a research centre for ongoing access to the records collected throughout the work of the Commission.

Independent Assessment Process The Independent Assessment Process (IAP) is the process to assist former students settle their claims for abuse they suffered at Indian Residential Schools. 
The IAP compensates former students for sexual abuse, serious physical abuse and certain other wrongful acts which caused serious psychological consequences for the individual. This compensation is available in addition to the Common Experience Payment.

Commemoration

The IRSSA provides \$20 million in funding to commemorate the legacy of Indian Residential Schools. Commemoration is about honouring, educating, remembering, memorializing and paying tribute to former students of Indian Residential Schools, their families and the larger Aboriginal community. It also acknowledges their experiences and the broad, systemic impacts of the Indian Residential Schools system.

The Government will provide funding to facilitate regional and national Commemoration initiatives that address the residential school experience and provide the opportunity to share the initiative with family and community.

Healing

The IRSSA provides for an additional endowment of \$125 million to the Aboriginal Healing Foundation, to continue to support healing programs and initiatives for a further five years following the Implementation Date.

The Church entities involved in the administration of Indian Residential Schools will contribute up to a total of $\$ 100$ million in cash and services toward healing initiatives.

\section{$\underline{\text { Appendix II }}$}

\section{The Apology}

On June 11, 2008, Canadian Prime Minister Stephen Harper issued the following statement of apology to former students of Indian residential schools.

Mr. Speaker, I stand before you today to offer an apology to former students of Indian residential schools. The treatment of children in Indian residential schools is a sad chapter in our history. In the 1870's, the federal government, partly in order to meet its obligation to educate aboriginal children, began to play a role in the development and administration of these schools.

Two primary objectives of the residential schools system were to remove and isolate children from the influence of their homes, families, traditions and cultures, and to assimilate them into the dominant culture.

These objectives were based on the assumption aboriginal cultures and spiritual beliefs were inferior and unequal.

Indeed, some sought, as it was infamously said, "to kill the Indian in the child."

Today, we recognize that this policy of assimilation was wrong, has caused great harm, and has no place in our country.

Most schools were operated as "joint ventures" with Anglican, Catholic, Presbyterian or United churches.

The government of Canada built an educational system in which very young children were often forcibly removed from their homes, often taken far from their communities.

Many were inadequately fed, clothed and housed.

All were deprived of the care and nurturing of their parents, grandparents and communities. First Nations, Inuit and Métis languages and cultural practices were prohibited in these schools. 
Tragically, some of these children died while attending residential schools and others never returned home.

The government now recognizes that the consequences of the Indian residential schools policy were profoundly negative and that this policy has had a lasting and damaging impact on aboriginal culture, heritage and language.

While some former students have spoken positively about their experiences at residential schools, these stories are far overshadowed by tragic accounts of the emotional, physical and sexual abuse and neglect of helpless children, and their separation from powerless families and communities.

The legacy of Indian residential schools has contributed to social problems that continue to exist in many communities today. It has taken extraordinary courage for the thousands of survivors that have come forward to speak publicly about the abuse they suffered.

It is a testament to their resilience as individuals and to the strength of their cultures.

Regrettably, many former students are not with us today and died never having received a full apology from the government of Canada.

The government recognizes that the absence of an apology has been an impediment to healing and reconciliation.

Therefore, on behalf of the government of Canada and all Canadians, I stand before you, in this chamber so central to our life as a country, to apologize to aboriginal peoples for Canada's role in the Indian residential schools system.

To the approximately 80,000 living former students, and all family members and communities, the government of Canada now recognizes that it was wrong to forcibly remove children from their homes and we apologize for having done this.

We now recognize that it was wrong to separate children from rich and vibrant cultures and traditions, that it created a void in many lives and communities, and we apologize for having done this.

We now recognize that, in separating children from their families, we undermined the ability of many to adequately parent their own children and sowed the seeds for generations to follow, and we apologize for having done this.

We now recognize that, far too often, these institutions gave rise to abuse or neglect and were inadequately controlled, and we apologize for failing to protect you.

Not only did you suffer these abuses as children, but as you became parents, you were powerless to protect your own children from suffering the same experience, and for this we are sorry.

The burden of this experience has been on your shoulders for far too long.

The burden is properly ours as a government, and as a country.

There is no place in Canada for the attitudes that inspired the Indian residential schools system to ever again prevail.

You have been working on recovering from this experience for a long time and in a very real sense, we are now joining you on this journey.

The government of Canada sincerely apologizes and asks the forgiveness of the aboriginal peoples of this country for failing them so profoundly.

We are sorry.

In moving towards healing, reconciliation and resolution of the sad legacy of Indian residential schools, implementation of the Indian Residential Schools Settlement agreement began on September 19, 2007. 
Years of work by survivors, communities, and aboriginal organizations culminated in an agreement that gives us a new beginning and an opportunity to move forward together in partnership.

A cornerstone of the settlement agreement is the Indian Residential Schools Truth and Reconciliation Commission.

This commission presents a unique opportunity to educate all Canadians on the Indian residential schools system.

It will be a positive step in forging a new relationship between aboriginal peoples and other Canadians, a relationship based on the knowledge of our shared history, a respect for each other and a desire to move forward together with a renewed understanding that strong families, strong communities and vibrant cultures and traditions will contribute to a stronger Canada for all of us. ${ }^{78}$

${ }^{78}$ http://www.cbc.ca/canada/story/2008/06/11/pm-statement.html 